\title{
The Nurturing of 'Good' Capitalists: Prisoners and Private Prison Labour
}

\begin{abstract}
This paper draws on a ten-month ethnographic study of private prison work in a UK prison to drawn attention to the prevalence of neoliberalism; even in an institution as secreted and isolated as a prison, the neoliberal ideology can flourish. Prisoners expressed attitudes heavily influenced by consumer culture and egoistic individualism. Most participants expressed a desire to become profitable entrepreneurs. On this basis, it should come as no surprise that prisoners admired the organizations sending work into prison. They despised the work, despised the prison for forcing them to conduct this work, but they were impressed by the firms sending this work in, who they saw as the ultimate exploitative entrepreneurs. They aspired to be entrepreneurs, and with limited opportunities to achieve this legitimately, and the exposure to poorly paid, unskilled work during their incarceration, many prisoners concluded that the best way to become entrepreneurs was through criminal means. Individualism and entrepreneurial rhetoric has clearly trickled down into the depths of our society, with those most vulnerable fighting for a place at the table; they have adopted, embraced and welcomed neoliberalism.
\end{abstract}

Key Words: Criminal Entrepreneurs; Ethnography; Neoliberalism; Prisoner; Prison

\section{Labour}




\section{Introduction}

In researching prisoners' attitudes towards private prison labour, there was an expectation that prisoners would view this negatively. Initially, these suspicions were confirmed; on entering Bridgeville prison, I was greeted with roars from prisoners about how exploitative prison work was and how unethical it was. When I approached prisoners to ask them about what they thought about prison work the overwhelming response was 'this is slave labour' This sentence resurfaced at almost every visit to Bridgeville prison. However, on closer inspection, this resentment was almost solely aimed at the prison itself. Prisoners did not appreciate that the institution imprisoning them would make a profit from their work, but they did not feel the same antipathy towards the private companies utilising their labour. Not only were they not resentful that private firms profited from their labour, they were impressed. They admired what they saw as the exploitation of their labour.

This paper draws on a ten-month ethnographic study of prison labour, exploring prisoners' experiences of and attitudes towards conducting work for private firms. This paper refers to this particular type of prison work as 'orange-collar work', this term derives from two roots; firstly, the prisoners' cinematic depiction in the orange jumpsuit and secondly the similarities between private prison labour and blue-collar work. The Social Exclusion Unit's (2002) report 'Reducing Re-offending by Ex-prisoners' suggests that employment reduces the risk of re-offending by between a third and a half. It is against this backdrop that UK policy has increasingly been driven towards improving the employment prospects and skills of offenders as a means of reducing re-offending (Fletcher, 2008), and for many, it is believed that the private sector is most equipped to achieve this (Pyle, 1997; Fenwick, 2005). The penal system has not been exempted from the growing neoliberal ideology that has become more 
embedded in modern society and politics. According to Crewe (2009) the core logic of modern prison governance is economic.

One part of this framework is a more forceful insistence on the financial accountability and frugality of government institutions. Imprisonment should be cheap, cost-effective and able to justify itself to a parsimonious public...According to this logic, it should also learn from commercial practices or have its functions contracted out to the private sector if viable and economical (Crewe, 2009: 17).

O’Malley (1999) argues that there are two currents working simultaneously within modern penality; neoliberalism, stressing individual responsibility, enterprise, accountability and efficiency and neo-conservativism, stressing discipline and punishment. This inevitably has implications for the running of the prison and the organisation of prison labour. This paper examines whether this surge has an impact on the prisoners themselves.

The paper will begin by critically discussing the phenomenon of neoliberalism, expanding on several elements, namely, consumerism and entrepreneurialism to situate this study within the relevant literature. The paper will then outline the methodological approach of the research, providing detail on the use of an ethnographic approach, utilising observations- both participant and non-participant, and semi-structured interviews. The paper will then proceed to the research findings which are divided into three sections; the first explores the materialistic attitudes of the prisoners, the second explores prisoners' relationship with entrepreneurship and their desires to own their own businesses, and the final data section explores prisoners' admiration for the businesses providing orange-collar work in Bridgeville, which interestingly, these same prisoners described as exploitative. The 
discussion and conclusion will then outline how these findings contribute to our understanding of neoliberal ideals at the micro level; how these ideals have been adopted and embraced by some of the most marginalised members of society.

\section{Literature Review}

A critical look at neoliberalism will be the focus of this literature review. Some of its key features are explored, namely, consumerism and materialism, individualism and entrepreneurialism. These will be discussed against the back drop of those individuals who find it most difficult to participate.

Neoliberalism, in the last two decades or so, has assumed the status of a dominant narrative or a regime of truth in the western world. Based on claims for the apparent superiority of laissez-faire or free-market principles, neoliberalism enshrines economic rationalism, competition, entrepreneurialism, individualism and independence, values that are represented as the antithesis of state responsibilities for living standards and care of the individual, the household or social groups (McDowell, 2004: 145-146).

Neoliberalism then is underpinned by individualism, entrepreneurialism and competition. Whilst many theorists have explored the impact of this on policy and society at large (McDowell, 2004; Wacquant, 2009; 2012), it is important to explore how this rhetoric has had an impact at the individual level; how neoliberal ideology has seeped into cultural norms and influences micro level attitudes and behaviours. 
A key assumption of neoliberal theory is that the opportunities for individual prosperity are dependent on participation in an unregulated labour market (McDowell, 2004). It is argued that neoliberal discourse devalues such notions as mutual dependence and care for others. George (1999) critiques neoliberalism's focus on competition arguing that this not only refers to competition between nations or firms but also between individuals. Thus, according to McDowell (2004: 146) 'the new neoliberal corporate capitalism has transformed citizens into consumers'.

In modern society, consumption has become key. As Hallsworth (2005) argues, young people produce and reproduce their identities based upon capitalist culture and consumption. However, the majority of individuals who buy into consumerist culture cannot afford to be a part of it (Hobbs, 2013); consumer culture and the void created by post-industrialism has promoted 'intense personal competition' and incited individuals to consume to a level that for many, cannot 'be lawfully sustain[ed]' (Currie, 1985: 278; Treadwell et al. 2013). So, in the hope of gaining entry into this exclusive club and the material possessions that go hand in hand with it, some individuals develop illicit means of obtaining these possessions that endorse the use of violence and rule breaking (Hallsworth, 2005).

Thus, many researchers have drawn the connection between increased neoliberal ideological views, leading to a flourish in consumerism and, to sustain this, a rise in criminal lifestyles. In fact, in researching prisoners, Crewe (2009) found that consumer possessions were important in signalling status in prison, especially for younger prisoners who were fixated on issues relating to clothing. One prisoner in Crewe's (2009) study described it as the 'peacock effect'. Crewe (2009) then, along with several researchers (Hallsworth, 2005; Hobbs, 2013; 
Treadwell, 2013), who have explored criminality have found many within this subterranean world to have adopted this lifestyle; a lifestyle that is almost impossible for them to participate in lawfully.

This ethos breaks away from the characteristic make-up of industrial society where solutions to everyday problems were always pragmatic and never 'magical' (Hall and Jefferson, 1976). It is suggested that the normalization of casual criminal behaviour 'should not be understood in terms of pathology, but in terms of predatory logic (Williams, 1989, 1992; Mieczkowski, 1990), where individualism and pecuniary advantage reign over communal priorities (Bourgois, 1995)' (Hobbs, 2013: 122). Thus, as Hobbs (2013) argues, if consumerism and material possessions are key, and some individuals are unable to afford this, it is likely that they will seek alternative, often illegal avenues to achieve this, perhaps this could be considered a type of embourgeoisement of the criminal class. Embourgeoisement is the concept of the working class increasingly adopting patterns of behaviour and emulating the styles of life previously held only by the middle classes (Jelin, 1974). It is argued that the growth of neoliberalism, bringing with it competition, individualism and consumerism has meant that, if we want to compete individually within society, we need to have 'things'; those from within working class communities thus emulate the consumption of the middle class, making purchases that are unsustainable.

As explained, to compete individually in society, or not necessarily compete, but at least participate in the game, many acquire 'things', but, consumerism alone is often not enough to participate. This can also be achieved through enacting other hallmarks of neoliberalism. For example, it is argued by most that neoliberalism also brings with it an emphasis on the 
possession of an 'entrepreneurial spirit'. Entrepreneurship has become an underlying focus in many of our institutions. For example, in researching neoliberal policy in Finnish education, Komulainen et al (2014) argue that entrepreneurship education reflects a neoliberal mentality of governance which aims at 'transforming the passive citizens of welfare societies into active enterprising selves' (Komulainen et al, 2014: 347. Rose, 1992) They argue that the neoliberal education system 'stresses the maximization of the self-steering capacities of individuals as vital resources for achieving private profit, the nation's economic competitiveness and social progress' (Komulainen et al, 2014: 347. Rose, 1992). And as has been explained within much of the criminology literature, we see this same emphasis on entrepreneurialism within the penal system (Garland, 1997; Hannah-Moffat, 2005; Crewe, 2009) The notion of enterprise culture gathered notoriety in the UK in the 1990s as an answer to neoliberal desires to encourage culture and economy to interconnect (Keat and Abercrombie, 1991; Rose, 1990; Sturdy and Wright, 2008). According to Komulainen et al (2014), the ideal individual qualities of an entrepreneur include competitiveness, independence, the need for achievement, and willingness to take risks. Interestingly, this final quality relates significantly with the risk-taking lifestyles of criminals, suggesting that entrepreneurialism is not something confined to the traditional organisation and 'upstanding citizens', entrepreneurialism can be and is embraced by those on the fringes of society.

This section has explored the literature on consumerism, entrepreneurialism, the growth of neoliberalism and its relation to class. The literature discussed here presents a critical picture of this relationship. This paper attempts to build on this literature by studying neoliberalism at a micro level; exploring the attitudes of a particularly vulnerable group of individuals. 


\section{Methodology}

This research took place within a private prison in the UK which, for the purpose of this study is named Bridgeville. Fieldwork took place over a ten-month period between 2012 and 2013. Contact was initially made with the company that runs Bridgeville and after approximately a year of negotiations, full access was obtained to the prison. I was provided with my own set of prison keys which gave me free rein of Bridgeville with the exception of prisoners' cells. The majority of fieldwork took place in the prison industries department within five key orange-collar workplaces. These included, a computer recycling workshop, a book packing workshop, a car part packing and industrial trolley strap workshop, a household plumbing assembly workshop and finally, a recycling and waste section, see table below.

\section{TABLE 1 HERE: PRISON WORKSHOPS}

The research adopted an ethnographic approach opting for depth and detail and an attempt to develop understanding and thick description. Participant and non-participant observation and semi-structured interviews were employed. According to Waquant (2002), this type of research is necessary as, by the $21^{\text {st }}$ century:

Observational studies depicting the everyday world of inmates all but vanished just as the US was settling into mass incarceration and other advanced countries were gingerly clearing their own road towards the penal state. The ethnography of the prison thus went into eclipse at the very moment when it was most urgently needed on both scientific and political grounds (Waquant, 2002: 385). 
The intention of the research was to understand prisoners' own perceptions of conducting orange-collar work. It was believed that, to understand this phenomenon and gauge a fair understanding of prisoner attitudes towards this work, research should take place within the (somewhat) 'natural' setting of the prisoner.

The erratic nature of prison (e.g. the high turnaround of prisoners), the need to build strong relationships with participants and the multi-layered details of orange-collar work meant that to build a solid and holistic understanding of this work, it was decided that conducting the study in only one institution over a lengthy period would be most suitable. This is also in keeping with most ethnographic studies of prison life where the focus has been one single establishment (Clemmer, 1958; Sykes, 1958; Morris and Morris, 1963; Mathiesen, 1965; Jacobs, 1977; King and Elliot, 1977; Crewe, 2009) 'with depth of analysis and richness of detail take precedent over breadth' (Crewe, 2009: 3). With regard to the decision to research a private prison it was believed that given private prisons' more outward emphasis on profit, they were likely to be more involved in orange-collar work and this indeed was found to be the case.

Forty semi-structured interviews were completed with prisoners from the orange-collar workshops. All interviews were digitally recorded and transcribed by hand. They lasted between twenty minutes and ninety minutes. A research schedule was used to ensure that the interviews remained focused in addressing the research aims: to understand prisoners' attitudes towards and experiences of conducting orange-collar work. However, the discussion in the interview was not restricted to this schedule- it was primarily used as a guide. Each of the four workshops accommodated thirty-five prisoners and Waste Management held around 
twelve prisoners. An attempt was made to select a similar number of prisoners from each workshop (see Table 2 below). It was hoped that this would provide a well-rounded picture and a detailed insight into prisoners' perspectives of prison work and its environment.

\section{TABLE 2 HERE: WORKSHOP INTERVIEWS}

The interview participants' ages ranged from eighteen to fifty-six and their prison sentences ranged between one and eight years. Almost half of the participants had been unemployed before coming to prison. Most expressed experience of labouring, construction, and other blue-collar work, primarily unskilled. However, one participant had worked in an estate agent office, another had worked in a care home and another had been a waiter. Still, these were all low paid work. Over half of the participants (twenty-four out of forty) had been to prison previously. Interviewees were chosen based on willingness. After conducting several months of observations within these workshops the researcher asked prisoners whether they would be willing to participate in an interview. Like many other female researchers (Gurney, 1985; Lumsden, 2009) sexual hustling was occasionally experienced which involved flirtatious behaviour, inquiries into the researchers' relationship status and sexually suggestive remarks. For example, when approached to ask whether they would participate in an interview, two prisoners responded by asking 'does it mean that I get to be alone in a room with you?' These individuals were automatically excluded from interviews as a precautionary measure.

Participant and non-participant observations were utilised, and a research diary was updated after every visit to Bridgeville. Participation was limited due to being a female outsider in an 
all-male prison; at five o'clock when the cell doors locked, I was able to go home ${ }^{1}$, therefore, participation refers to the joining in with the completion of the work.

This section has provided insight into the ethnographic approach employed, utilising interviews and observation. This section has also provided detail on the context of the research, both the setting, the work the prisoners conducted and the prison itself. It has also provided some reflexive insights on the role of the researcher in conducting this research and the inescapable limitations that this may have had on the research.

\section{Orange-Collar Roots, White-Collar Dreams}

Prisoners expressed attitudes which appeared to be heavily influenced by consumer culture and egoistic individualism. During a conversation in the Waste Management Department, the prisoners discussed, in detail, the importance of getting the best and most expensive clothes and toys for their children. Similar aspirations were expressed whilst chatting to a group of prisoners in Workshop 1; they competitively discussed how they spoiled their children. When discussing the birth of his daughter, one prisoner, Jackson, proudly explained how he had immediately bought her a custom made pink velour tracksuit, personalised with her name on it. For most of the men I spoke to, money was the be-all and end-all, their ultimate objective. Low-income jobs would not be able to satisfy their hedonistic, material-driven lifestyles and as such alternative avenues were explored. These alternative avenues are essentially what led them to Bridgeville.

Prisoners who had worked as drug dealers or thieves outside of prison told me how much money they would earn a day and what they would buy with this money. Several researchers

\footnotetext{
${ }^{1}$ Inevitably there is much to be discussed with regard to being a female outsider and researcher in this environment but this will not be explored in this paper.
} 
have found that criminal activity such as drug dealing is more profitable on an hourly basis than legitimate jobs available to the same persons' (despite the increased risk of imprisonment and subsequently a long stretch of no earnings) (Reuter et al. 1990; Fagan, 1992; 1993; Hagedorn; 1994). As such, when one is driven by material things, they are likely to seek out the 'job' that allows them to earn the greatest amount of money in the shortest amount of time. One prisoner, Paul, a cocaine dealer from Workshop 1, told me that he regularly earned $£ 3,000$ a day from dealing drugs. On the same day he would go shopping and spend a large amount of this on a new outfit to wear out to town in the evening. He explained that he would go out on a Saturday night, in his new outfit and 'blow the rest of the money on buying champagne' for himself, his friends and women that he would meet that night.

The large sums of money that can be accumulated by criminality was also illustrated by Nelson from workshop 4, who explains why he continues to deal drugs rather than join the legitimate labour market:

I was working (legitimate employment) and I was making about $£ 150$ a week but then I would wake up in the morning and make that much money in one hour (drug dealing) and I'd be thinking I'd rather do that than go to work. (Nelson, 25yrs, Workshop 4).

The materialist concern with money and consumer durables inevitably coloured prisoners' views of the low-skilled, low-wage work that they were required to undertake at Bridgeville. This paper highlights the redundancy of low-skilled prison work as a means of offering an alternative pathway to the realisation of prisoners' materialistic ambitions. As such, I draw 
the conclusion that crime, the type of crime in which you can accumulate quick and easy money, and lots of it, would seem like a much more appealing option for many, particularly those prisoners who have already had a taste of this lifestyle.

A criminal career also offered a certain level of job satisfaction. As Hobbs (2013) explains, 'there is now a complex field of transitional possibilities featuring markets offering something more interesting than a 'McJob' (Craine, 1997; MacDonald, 1998; Ritzer, 2004; Hobbs, 2013: 134) and something that offers a more immediate financial reward (Hobbs, 2013).

The materialistic attitudes expressed by prisoners went hand in hand with their aspirations to become entrepreneurs. In my interviews and conversations with prisoners in the orange-collar workshops I felt it appropriate to explore their attitudes to private capital - especially the companies that they were effectively working for a rate much lower than the national minimum wage. The results of these discussions threw up some surprising insights about prisoners' admiration for entrepreneurs and their desires to emulate this, often in a legitimate sense rather than in a criminal sense (although their inability to enact this legitimate entrepreneurialism led to several attempting to pursue this through criminal activity).

\section{Inside the Dragon's Pen: The Mainstreaming of Crime and the Embourgeoisement of the Criminal Class}

Several researchers have noted the growing perception of entrepreneurship as virtuous, with the representation of entrepreneurs as 'super-heroes' (Williams, 2006; Jones and Spicer 2006, Williams and Nadin, 2012: 896). This admiration for, and growth of, entrepreneurialism has 
also been identified within the informal economy (Williams, 2006; Williams and Nadin, 2012) and has also been found within working class communities (Hobbs, 2013). This admiration for legitimate entrepreneurialism and a materialistic, aspirational lifestyle was evident amongst the participants of my research; they embodied a type of embourgeoisement. They more readily identify with (or wish to be identified with) an entrepreneurial, consumerist class rather than a working or criminal class (Harvey, 2011). So, while the individuals I have discussed may not receive the same earnings as middle-class individuals they still strive to achieve their more consumer driven lifestyles and status. Luke articulated this admiration for an entrepreneurial spirit and a motivation for profit when asked what he wanted to do after prison:

[I've been] watching The Apprentice and all that for years, I've read Lord Alan Sugar's book and Richard Branson's book, I like them all I do... [I'd like to work in] Business management or something like that. I want to be a manager, owner or CEO of a big company, that's the ideal dream, with a thousand people under me... Top of the table at the press conference and everything, I think I've got what it takes as well, if I use my head now, I'm only 21 now, I'll be out when I'm 24, if I use my head now I'll hopefully be a millionaire by the age of 30 (Luke, 21yrs, Workshop 2).

Luke was incredibly optimistic and ambitious about his potential to become a rich entrepreneur; he felt it would be possible to leave prison and become an entrepreneur within the space of nine years and whilst I respected Luke's enthusiasm it also seemed highly fantastical. Prisoners such as Luke admired Alan Sugar and Richard Branson. Luke put them on a pedestal as 'self-made men' that he aspired to be like. When I asked prisoners what they would like to do for employment after prison most participants expressed that, if they did envisage living a 'straight' life, they wanted to be businessmen and start their own 
companies. Of the forty prisoners interviewed every one of them mentioned a desire to become a business owner in some way or another as illustrated in the following quotes:

Jamie: I dunno like, I wants to own my own business, like a car valeting thing or something like that

Researcher: Invest in it and get involved or?

Jamie: Invest in it and I don't know, I'd get involved but obviously I'd put some money to get, just to make some money like (Jamie, 22yrs, Workshop 1).

Hopefully, if I can, if I get enough money together [I can] look into going on to these Prince's trust things and start up a small business like, I'd need to look into it a bit more (Joe, 39yrs, Workshop 1).

[after prison I'd like to] maybe have my own business, I'd love that. My uncle did it, he had nothing- a 3-bedroom council house... and now his business is worth 2 and a half million. He does all roofing and flooring materials and he's got his own yard and that (Kyle, 26yrs, Workshop 3).

Like many prisoners, Gurdeep did not enjoy the unskilled nature of the work he was conducting in prison and did not feel it would be useful for him in his working life outside of prison. Gurdeep and many others instead saw business ownership as the holy grail:

Researcher: Do you think this work will help you get a job when you leave?

Gurdeep: Nah, nah, nah, I want to do something, a future something where I can progress, maybe do a family business or something. Like I said I might want to go 
back into fruit and veg or something so that maybe when my kids are older they can have it as a family business or something. I want to do something where there is profit, not where there is a set wage and you're on $£ 10$ an hour and that's what you're going to be on for the rest of your life. I want to do something to benefit me and my kids (Gurdeep, 26yrs, Workshop 4).

Despite these positive aspirations, Beder (2000) argues that 'for the millions of people in precarious employment, the old rhetoric of the self-made man and work leading to success has little grounding in the reality of their experience' (Beder, 2000: 145). Hobbs (2013) argues that within post-industrial society youth groups are becoming increasingly market orientated (Hobbs, 2012; 2013). But, when they are unable to seek out these opportunities legitimately, for many the drug trade 'offers an accessible alternative sphere of enterprise to declining opportunities in traditional male employment' (Hobbs, 2013: 116). Hobbs (2013) suggests that the quest for excitement and status by many youth subcultures, particularly from the working class can often be satisfied by these illegitimate avenues as they can offer an alternative career trajectory (Slaughter, 2003, Hobbs, 2013). This seemed to be the case for many of the participants I interviewed; their possession of entrepreneurial attitudes but without the opportunities, qualifications and capital to enact this in a legitimate sense meant that many had opted to exit legitimate employment (if they had ever entered at all) and move towards criminal careers instead. 


\section{From Don Corleone to Donald Trump: Prisoner Identification with Freewheelin' Capitalism and Self-Afflicting Individualism}

The data outlined thus far has highlighted the way that many prisoners adopted materialistic, entrepreneurial, profit-driven attitudes for their own future. This suggests, like previous research has done, that these individuals have adopted neoliberal attitudes and behaviours. This has primarily been related to their lives outside of prison, but this was taken one step further when we began to discuss their experiences inside prison.

During several interviews, prisoners demonstrated individualistic and fatalistic attitudes toward their incarceration. Despite the fact that all participants came from low socioeconomic backgrounds, many had very difficult upbringings, grew up in foster care and one prisoner even witnessed the murder of his father, they still explained that it was their 'own fault' that they had ended up in prison. For example:

You're in jail, there's no point complaining like init, it's your fault for being in here, you can't start moaning about everything around you like, just deal with it (MacKenzie, 18yrs, workshop 1).

The hardest part was seeing my family seeing me like that, but it's my own fault what I'm in here for so... (Jake, 22yrs, Workshop 1).

It doesn't bother me...just take it has it comes...I go out I'm a naughty boy and then I deserves to come to jail if I get caught...I does stupid things I do, I'll be honest with you, rash decisions...never mind...I think (prison is) too easy these days, people don't mind coming here, we've got too many rights these days (Ryan, 25yrs, Workshop 2). It was not just MacKenzie, Jake and Ryan who felt that the responsibility of imprisonment lay solely with themselves. When discussing orange-collar work with Will, a prisoner from 
workshop 4, he explained that as a prisoner, he 'deserved' to be punished, and if that meant Bridgeville would make a profit from this punishment, so be it:

Researcher: Some people say that the place that is punishing them shouldn't be making money

Will: You can't say that- we're getting punished because we deserve to get punished. If I didn't do what I did wrong, then I wouldn't be here. So, I can't hold that against anyone else because I'm in here. So, I'm not going to be bothered what they do, if they want to earn money, earn money (Will, 25yrs, Workshop 4).

I had naively assumed that prisoners would be angry about the exploitation of their labour and its futility as a rehabilitative tool. But, in fact, many of the prisoners I interviewed, even those who felt orange-collar work was exploitative, told me that they 'wish they had thought of it'.

During interviews with prisoners I asked their opinion on the involvement of private firms and the development of a profit motive in prison work. During my observations of the workshops prisoners expressed disdain for their contemptible pay (with most being on $£ 15$ a week) when profit was being made at their expense. Their responses were particularly interesting as they told me that they felt the work was exploitative, referring to it as 'slave labour'. In ten months of observations inside Bridgeville, this phrase was used almost every time I visited, sometimes angrily and sometimes in jest, but consistently nonetheless. Despite making these comments, they admired those who they saw as responsible for the exploiting. In typical Marxist form the prisoners in this study willingly consented to their own exploitation and interestingly, they admired it. 
After several months of observations, interviews and informal discussions, it became clear that prisoners were only angry about exploitation by Bridgeville and prison authorities; they made clear lines of distinction between Bridgeville as the exploiter to be criticised and private companies contracting out work to Bridgeville as commercial opportunists to be revered. Indeed, the private contractors were regarded with admiration and respect. Prisoners venerated the need to make money by any means necessary. They believed that the concept of sending work into prison to be completed was a smart business model as it would increase company profits. But prisoners' admiration did not extend to Bridgeville; many held the view that the deprivation of liberty is a core state function, a responsibility that should not be contracted out to private companies for them to derive profit (Liebling and Crewe, 2012).

Prisoners admired the entrepreneurial, easy profit tactics employed by the private firms. Lori from Workshop 1 expressed very positive views of capitalism (an attitude which I found amongst almost all of prisoners I interviewed). He was disdainful of the profits that Bridgeville generate from orange-collar work, but he explained that it makes business sense for private firms to hire prisoners:

Lori: They get paid loads. I read some of the job cards and they're getting paid stupid amounts of money, some of them are like forty grand.

Researcher: Who's getting paid, the prison?

Lori: Yeah. When we get big orders, they're getting paid grands and they're paying like two hundred odd pounds a week to the prisoners... what they've got to pay for is the prisoners, the electric and the officers; they're making so much money this jail.

Researcher: So, who annoys you, the prison or the private contracts or neither? 
Lori: Nah, the private contracts obviously they're alright but [in terms of the prison] it's obviously wrong that they make prisoners work all that time and they do all that work for nothing.

Researcher: You said obviously the private contracts are fine, why do you say that?

Lori: Like, if I was a business, I'd have jails, I wouldn't but I- they're making money aren't they. That's all they're about is making money. Obviously, it's cheaper to have us doing it than it is to have a warehouse on road so.

Researcher: So, you respect that?

Loris: Yeah

(Lori (24yrs), Workshop 2).

Bill, Jamie and Joe also expressed admiration of the private firms' involvement in prison labour:

I wish I'd thought of that. Private companies are there to make money, a black and white jail is a not-for profit organisation, so they're there to rehabilitate you and get you out. [Private prisons]- They want to make money (Bill (44yrs), Workshop 3).

It's pretty cool like. It doesn't bother me. I wish I'd thought of it, I wouldn't be sat here now, I'd be making bloody loads of money (Joe (39yrs), Workshop 1).

Researcher: What about the private company then, do you have any problem with them? 
Jamie: No, because honestly, I'd love my own business making money like that, so fair do's to them, that's what I think (Jamie (22yrs), Workshop 1).

In fact, this admiration for profit applied to almost all forty of those prisoners that I interviewed. When prisoners believed that the prison and the private firms were profiting from their labour, they were still inclined to admire the private firms and view their use of cheap labour as something they would like to imitate if they were to develop their own business, as emphasised by Luke and Will below:

Researcher: What do you think about privately contracted work?

Luke: I think it's alright, If I owned a company I think it would be brilliant because you're paying them, you're getting cheap work... If I owned a company, I'd be straight in here- cheap as chips really.

Researcher: But as you're the one having to work for low money what do you think of that?

Luke: Because I’ve worked all my life, I wouldn't do this out there for $£ 25$ a week because you couldn't... I think it's exploiting us a little bit really. It said on the news yesterday that they think it's exploiting us. It's slave labour and stuff (Luke (21yrs), Workshop 2).

JP: And what about the private companies?

L: Best of luck to them, they're saving a bit of money, I'd do the same if I had a private company, you would wouldn't you? If you can save money and make more money, fair play to them, if they'd done that in a factory, how much would they have 
to pay then- they're saving hundreds and hundreds of pounds, probably thousands a week (Will (25yrs), Workshop 4).

Luke explains that, whilst he feels the work is 'slave labour' and exploitative, he still thought it was 'brilliant' that private firms were able to utilise such cheap labour, John also shared this point of view:

If it [privately contracted work] wasn't being done here [Bridgeville], it would be done somewhere else- its work that's got to be done. A lot of people would say its slave labour or they're using us [but] they've got to find something to occupy people's time here, so if work comes from outside and it's got to be done, so be it. Alright, the outside companies are having it done at a lower rate, but if I was a business man, I'd want my stuff done at a lower rate. You're not doing it to punish people, it's just the way business works (John (42yrs) Workshop 2).

John, saw the use of orange-collar work in prison as logical for all involved; it generated money for Bridgeville, the private firms and kept prisoners occupied. With the privatisation of different elements of the penal system, often the 'business case' can be prioritised over the 'moral case' (Liebling, 2012), and this study has found that the prisoners within this institution approve of this logic, Bill, a prisoner from workshop 4 spoke candidly and admiringly of both the private firms and Bridgeville's quest from profit.

It's all bullshit. All it is, is for Bridgeville to make money off of it. It's not going to rehabilitate you; it's just to make money off of you... They pay me $£ 15$ a week to do a job they charge $£ 43$ for- for one pallet... I wish I'd thought of it before I stabbed my missus.... I could have started my own jail, I could be a millionaire by now...I wish 
I'd thought of it, cracking idea. You've got clients who are always going to come back all the time...there's a quicker turnover than McDonalds here. Boys are let out, they're out and then they come back in, out, back in, longer sentences, longer sentence, it's a money-making scheme (Bill (44yrs old), Workshop 4).

\section{Discussion and Conclusion}

This paper has attempted to outline the deep-rooted neoliberal attitudes that are held amongst the prisoners within this study. It serves to highlight the widespread nature of the many elements of neoliberalism, and the way that it has taken root in society, even amongst those who, in many ways, have opted out of mainstream society; those who are considered to be vulnerable and outsiders not only accept these values but excitedly embrace them.

In an attempt to understand prisoners' attitudes towards conducting prison work for private companies this research has developed several themes regarding prisoners' attitudes. Firstly, in line with many researchers exploring working class society, it was found that the prisoners of this study also held strong consumerist and materialistic desires. Prisoners spoke profusely throughout the ten-month observational study about their material desires, in their pursuit of this, many explained that in assessing their options, they believed this could best be achieved through criminal activities. This is unsurprising and in many ways a rational option; with limited social, cultural and economic capital, barriers are raised to these individuals to allow them to earn money. Now, what is important here is that, yes, they could potentially obtain employment outside of prison and there are many ways that they could work towards earning a living in legitimate employment, but, because of their eager need to participate actively and 
overwhelmingly in consumer culture, many of the prisoners in this study did not believe that legitimate, regular employment would allow them to achieve the lifestyle they desired.

This brings us to the next theme, prisoners desire to become entrepreneurs. All interviewees expressed a desire to own their own business, they held business men and entrepreneurs to high esteem. All forty interviews expressed a desire to own their own business, and whilst some had every intention of attempting to pursue this legitimately, many were resigned to the fact that the easiest and quickest way for them to be their own boss, to gain esteem, status and a reputation amongst their peers, would be to become a 'criminal entrepreneur' and as such, several had embarked-on careers as drug dealers or professional robbers, which is exactly what has led them to Bridgeville.

Finally, in embracing these neoliberal ideals; consumerism, competition, individualism and entrepreneurialism, it is no surprise that the prisoners in this study saw nothing wrong with orange-collar work. More than this, they thought it was smart and 'good business sense'. They believed this work was exploitative, they believed that their labour was worth much more than the wages they were earning, but rather than see this has a negative thing, they saw it as something to be admired and were only disappointed that they had not thought of this idea themselves.

This uncritical and seemingly fatalistic acceptance of profit-making, by whatever means necessary, in some ways, mirrors and also legitimises criminal lifestyles. In itself this is an interesting commentary on modern capitalist enterprises - when your cheerleaders include not only the CBI and Conservative politicians but also criminals. The rise in neoliberalism 
has brought with it a 'tough on crime' approach (Wacquant, 2009, Crewe, 2009). As Crewe (2009: 25) argues, both main political parties in the UK 'continue to scrabble for the macho penal high-ground, creating a bi-partisan rhetorical chorus of 'tough sentencing'. And yet, under this backdrop, it is this same ideology in which this paper suggests crime takes root and flourish. The criminal class agree with and applaud this ideology, so much so that they adopt it in their own attitudes and importantly in their own behaviours which inevitably then has the greatest negative impact on them, the criminal/prisoner, when they find themselves within a criminal justice system whose rhetoric holds them wholly accountable and adopts a 'tough on crime' approach.

This paper contributes to an understanding of neoliberalism at the microlevel, it aims to demonstrate how this ideology is adopted by even the most vulnerable groups in society. Those who sit on the very outskirts of our society have still been influenced by the ideals of individualism, competition, consumerism and entrepreneurialism amongst others. The very ideology that oppresses, exploits and manipulates them and labels them criminals.

\section{References}

Beder, S. (2000) Selling the Work Ethic: From Puritan Pulpit to Corporate PR. London: Zed. Bourgois, P. (1995) In Search of Respect: Selling Crack in El Barrio. Cambridge: Cambridge University Press.

Clemmer, D. (1958) The Prison Community. New York; Holt, Rinehart and Winston.

Craine, S. (1997) The 'Black Magic Roundabout': Cyclical Transitions, Social Exclusion and Alternative Careers, In: R. MacDonald (eds.). Youth, the 'Underclass' and Social Exclusion. London: Routledge, pp. 130-52.

Crewe B. (2009) The Prisoner Society: Power, Adaptation and Social Life in an English Prison. Oxford: Oxford University Press.

Currie, E. (1985) Confronting Crime: An American Challenge. New York: Pantheon. 
George, S. (1999) A short history of neoliberalism: twenty years of elite economics and emerging opportunities for structural change. Paper presented to the Conference on

Economic Sovereignty in a Globalising World, Bangkok, 24 -26 March.

https://www.tni.org/en/article/short-history-neoliberalism (last accessed 6 January 2018).

Fagan, J. (1992) Drug Selling and Licit Income in Distressed Neighborhoods: The Economic Lives of Drug Users and Drug Sellers. In: G. E. Peterson and A. V. Harrell. Drugs, Crime and Social Isolation: Barriers to Urban Opportunity. The Urban Institute: 99-146.

Fagan, J. (1993) The political economy of drug dealing among urban gangs, In: R. Davis, A. Lurigio and D. P. Rosenbamn, (eds). Drugs and community. Springfield, IL: Charles Thomas: $19-54$.

Fenwick, C. (2005) Private Use of Prisoners' Labor: Paradoxes of International Human Rights Law. Human Rights Quarterly, Vol. 27: 249-293.

Fleming, P. (2013) In Search of Corporate Social Responsibility: Introduction to Special Issue. Organization, Vol. 20(3): 337-348.

Fletcher, D. R. (2008) Offenders in the Post-Industrial Labour Market: From the Underclass to the Undercaste? Policy and Politics, Vol. 36(2): 283-297.

Fletcher, D. R. (2011) The Development of Working Prisons: Transforming Inmates from the Lumpenproletariat to the Contingent Workforce? British Journal of Community Justice, Vol. 9(1/2): 111-124.

Garland, D. (1997) "Governmentality” and the problem of crime: Foucault, criminology, sociology. Theoretical Criminology, 1: 173- 214.

Gurney, J. N. (1985) Not One of the Guys: The Female Researcher in a Male-Dominated Setting. Qualitative Sociology, Vol. 8(1): 42-62.

Hagedorn, J. (1994), Neighborhoods, Markets and Gang Drug Organization. Journal of Research in Crime and Delinquency, Vol. 31: 264294.

Hall, S. and Jefferson, T. (1976) Resistance through Rituals (eds). London: Hutchinson Centre for Contemporary Cultural Studies.

Hallsworth, S. (2005) Street Crime. Cullompton: Willan.

Hannah- Moffat, K. (2005) Criminality, need and the transformative risk subject: Hybridization of risk/need in penality. Punishment and Society 7(1): 29-51.

Harvey, L. (2011) Critical Social Research. London: Unwin Hyman.

Hobbs, D. (2013) Lush Life: Constructing Organised Crime in the UK. Oxford: Oxford University Press.

Jacobs, J. B. (1977) Stateville: The Penitentiary in Mass Society. Chicago, IL: University of Chicago Press. 
Jelin, E. 1974. The Concept of Working-Class Embourgeoisement. Studies in Comparative International Development, Vol. 9(1): 1-19.

Jones, C. and Spicer, A. (2006) 'Outline of a Genealogy of the Value of the Entrepreneur. In: G. Erreygers and G. Jacobs (eds). Language, Communication and the Economy Amsterdam: John Benjamins: 42-69.

Keat, R. and Abercrombie, N., eds (1991) Enterprise Culture. London, Routledge.

King, R. D. and Elliott, K. (1977) Albany: The Birth of a Prison-End of an Era. London: Routledge.

Komulainen, K., Naskali, P., Korhonen, M. and Keskitalo-foley, S. (2014) Internal Entrepreneurship - a Trojan horse of the neoliberal governance of education? Finnish preand in-service teachers' implementation of and resistance towards entrepreneurship education. Journal for Critical Education Policy Studies, 9 (1): 342-373.

Liebling, A. and Crewe, B. (2012) Prison Life, Penal Power and Power Effects, In: M. Maguire, R. Morgan. and R, Reiner $\left(5^{\text {th }} \mathrm{Ed}\right)$. The Oxford Handbook of Criminology Oxford: Oxford University Press: 895- 927.

Liebling, A., Crewe, B. and Hulley, S. (2012) Values, Practice and Outcomes in Public and Private Sector Prisons, In: V. Heylar - Cardwell. Delivering Justice: The Role of the Public, Private and Voluntary Sector in Prisons and Probations. London: British Justice Alliance: 16- 24.

Lumsden, K. (2009). 'Don't Ask a Woman to Do another Woman's Job': Gendered Interaction and the Emotional Ethnographer. Sociology, 43(3): 497-513.

MacDonald, R. (1998) Youth, Transitions and Social Exclusion: Some Issues for Youth Research in the UK. Journal of Youth Studies, Vol. 1(2): 163-176.

Mathiesen T (1965) The Defences of the Weak. A Sociological Study of a Norwegian Correctional Institution. London: Tavistock Publications.

McDowell, L. (2004) Work, workfare, work/life balance and an ethic of care. Progress in Human Geography, 28 (2): 145-163.

Mieczkowski, T. (1990) Drugs, Crime, and the Failure of American Organized Crime Models. International Journal of Comparative and Applied Criminal Justice, Vol. 14(1): 99106.

Ministry of Justice. (2013) Proven Re-offending Quarterly July to June 2011. London: Ministry of Justice.

Morris, T. and Morris, P. (1963) Pentonville: A Sociological study of an English Prison. London: Routledge.

O’Malley, P. (1999) Volatile and Contradictory Punishment. Theoretical Criminology 3(2): 175-196 
Prison Reform Trust. (2013). Prison: The Facts. Bromley Briefings Summer 2013. London: Prison Reform Trust.

Pyle, K. L. (1997) Prison Employment: A Long Term Solution to the Overcrowding Crisis. Boston University Law Review. Vol. (77): 151-180.

Reuter, P., MacCoun, R. and Murphy, P. (1990) Money from Crime: A Study of the Economics of Drug Dealing in Washington, D.C. Report R-3894. Santa Monica CA: The RAND Corporation.

Ritzer, G. (2004) The McDonaldization of Society: Revised New Century Edition. London: Sage Publications Ltd.

Rose, N. (1990) Governing the Soul: The Shaping of the Private Self. London: Routledge.

Rose, N., 1992. Governing the enterprising self. In P. Heelas \& P. Morris, eds., The values of the enterprise culture. The moral debate. London: Routledge: $141-164$.

Slaughter, P. (2003) Of Crowds, Crimes and Carnivals, In: R. Matthews and J. Young, (eds), The New Politics of Crime and Punishment. Cullompton: Willan: 178-198.

Social Exclusion Unit. (2002) Reducing Reoffending by Ex-Prisoners. London: Office of the Deputy Prime Minister.

Sturdy, A. and Wright, C. (2008) A Consulting Diaspora? Enterprising Selves as Agents of Enterprise. Organization, 15(3): 427-444.

Sykes, G.M. (1958) The Society of Captives: A Study of a Maximum Security Prison. Princeton, New Jersey: Princeton University Press.

Treadwell, J., Briggs, D., Winlow, S. and Hall, S. (2013) Shopocalyspe Now. British Journal of Criminology, Vol. 53: 1-17.

Wacquant, L (2009) Punishing the Poor: The Neoliberal Government of Social Insecurity. UK: Duke University Press.

Wacquant, L. (2002) The Curious Eclipse of Prison Ethnography in the Age of Mass Incarceration. Ethnography, Vol. 3: 371-398.

Wacquant, L. (2012) The Wedding of Workfare and Prisonfare in the 21 st Century. Journal of Poverty, 16 (3): 236-249.

Williams, C. and Nadin, S. (2012) Tackling the Hidden Enterprise Culture: Government Policies to Support the Formalization of Informal Entrepreneurship. Entrepreneurship and Regional Development, Vol. 24(9-10): 895-915.

Williams, C. C. (2006) The Hidden Enterprise Culture: Entrepreneurship in the Underground Economy. Cheltenham: Edward Elgar.

Williams, T. (1992) Crack House. Reading, MA: Addison-Wesley.

Williams, T. (1989) The Cocaine Kids. Reading, MA: Addison-Wesley. 


\section{Tables}

Table 1: Prison Workshops

\begin{tabular}{|l|l|l|}
\hline Workshop & Contract & Work \\
\hline $\begin{array}{l}\text { (approx. 35 } \\
\text { prisoners) }\end{array}$ & $\begin{array}{l}\text { CrashCo. } \\
\text { ElectroWire }\end{array}$ & $\begin{array}{l}\text { Breaking apart computer items such as desktop computers, } \\
\text { printers, scanners, separating these parts to be recycled. } \\
\text { Packing electrical rubber wires. Due to the inconsistency of this } \\
\text { contract, only a handful of prisoners are assigned to this work as } \\
\text { and when it comes in. }\end{array}$ \\
\hline $\begin{array}{l}2 \\
\text { (approx. 35 } \\
\text { prisoners) }\end{array}$ & BookSmart & $\begin{array}{l}\text { Packing books, stickering books, shrink wrapping books and } \\
\text { quality checking them to make sure the pages are all written in } \\
\text { the same language. }\end{array}$ \\
\hline $\begin{array}{l}3 \\
\text { (approx. 35 } \\
\text { prisoners) }\end{array}$ & Partpro & $\begin{array}{l}\text { Wrapping straps through a plastic case, rolling them and packing } \\
\text { them. The product is then sold to supermarkets and other } \\
\text { companies and is used to pull large warehouse trolleys. }\end{array}$ \\
\hline $\begin{array}{l}4 \\
\text { (approx. 35 } \\
\text { prisoners) }\end{array}$ & FlushCo. & $\begin{array}{l}\text { Repackaging small car parts and stickering them. } \\
\text { plumbing parts such as toilet flushes. When made, these parts } \\
\text { were repackaged by prisoners }\end{array}$ \\
\hline $\begin{array}{l}\text { Waste } \\
\text { Management } \\
\text { (approx. 10-12 } \\
\text { prisoners) }\end{array}$ & Scraplt. & $\begin{array}{l}\text { This job is performed outside (still in Bridgeville). Some workers } \\
\text { collect the bins from all over the prison. Others then separate } \\
\text { the waste into recyclable groups such as plastic, cardboard and } \\
\text { food waste. Then 1 or 2 of the workers use a bailer to compress } \\
\text { the paper into small bundles ready to be taken away by Scraplt } \\
\text { who have a contract with the prison to purchase their recycling. }\end{array}$ \\
\hline
\end{tabular}

Table 2: Workshop Interviews

\begin{tabular}{|l|l|}
\hline Workshop & Number of Interviews \\
\hline Workshop 1 & 8 \\
\hline Workshop 2 & 10 \\
\hline Workshop 3 & 8 \\
\hline Workshop 4 & 8 \\
\hline Waste Management & 6 \\
\hline
\end{tabular}

Absence of context in neoliberal ideology 